\title{
Effects of project-based learning in a Japanese language course: A case study from the Yersin University of Dalat
}

\author{
Nguyen Thi Diem $\mathrm{Ha}^{1 *}$ \\ ${ }^{1}$ Department of Foreign Languages, Yersin University of Dalat, Vietnam \\ *Corresponding author: diemhamikawa@gmail.com
}

\begin{tabular}{|c|c|}
\hline ARTICLE INFO & ABSTRACT \\
\hline $\begin{array}{l}\text { DOI: } 10.46223 / \mathrm{HCMCOUJS} . \\
\text { soci.en.10.2.958.2020 }\end{array}$ & $\begin{array}{l}\text { Project-based learning (PBL) is an approach that can } \\
\text { improve learner motivation and enhance learner autonomy. } \\
\text { This report describes the implementation of a clarified project } \\
\text { with a poster and video clip linked PowerPoint presentation } \\
\text { structure and the student perceptions of this project within a }\end{array}$ \\
\hline Received: September $3^{\text {rd }}, 2020$ & Japanese language course at the Department of Foreign \\
\hline Revised: October $30^{\text {th }}, 2020$ & Languages, Yersin University of Dalat. This correlational study \\
\hline Accepted: November $10^{\text {th }}, 2020$ & $\begin{array}{l}\text { used a questionnaire with a sample size of } \mathrm{n}=31 \text { to gather data } \\
\text { from the participants. Descriptive statistics, Cronbach' alpha } \\
\text { measurement, and Pearson's correlation were means for the } \\
\text { analysis of responses. Results showed that the students' }\end{array}$ \\
\hline Keywords: & attitudes towards the project were favourable, and the \\
\hline $\begin{array}{l}\text { project-based learning, Japanese } \\
\text { language, motivation, autonomy, } \\
\text { correlational study }\end{array}$ & $\begin{array}{l}\text { respondents gained significant improvement in learning } \\
\text { motivation and autonomy. Findings also indicated that the } \\
\text { teacher's instructions were helpful throughout the process. }\end{array}$ \\
\hline
\end{tabular}

\section{Introduction}

It has become universally acknowledged that the elements of the present-day economic activities require joining people including employers, employees, and even customers a range of abilities that permits them to think autonomously and react successfully to an unconstrained changing world. Thus, educational institutions must equip learners with not only job-specific skills but so-called soft skills as well. Modern teaching-learning processes demand students a high degree of learning autonomy. In other words, learners should be able to take charge of their learning. Meanwhile, considering as one of Confucian heritage culture (CHC) countries and territories, Vietnam has an education that has been rooted deeply in the Confucian tradition for years. Under such a circumstance, it should come as no surprise that the learning characteristics of Vietnamese students were said to be passive and rote-learning what received from the teacher (Nguyen, 2014; Thompson, 2009). In recent years, according to the author's observation, students at the Yersin University of Dalat have shown a slightly positive towards an active learning approach in general. However, many of them were still favourable a learning mode of rote memorization and teacher dependence. These students do not often utilize expository abilities and inventive thinking in their learning process. This learning leads to difficulty not only for the students to meet the growing demand of a challenging workforce but also for the teachers to implement effective teaching methods, especially in foreign language learning. This study aims to examine how a project can be a tool for teachers and students to meet their expectations in a Japanese language course. 


\section{Literature review}

\subsection{Project-based learning}

As PBL theory and practice are abundant in many books, review articles and research papers (e.g., Beckett \& Slater, 2019; Condliffe et al., 2017; Dewey, 1938; Thomas, 2000), the following only gives very brief information relating to this research. Project-based learning (PBL) is an approach that carries out a learning-teaching process using projects to obtain learning outcomes (Thomas, 2000). The projects used in PBL are complex tasks that mobilize students participating in activities such as design, problem-solving, decision making, or investigation (Jones, Rasmussen, \& Moffitt, 1997). These complex tasks encourage students to work semi-autonomously and culminate in real products or presentations (Thomas, Mergendoller, \& Michaelson, 1999). In other words, a PBL project should be designed as a student-centered approach and involving the creation of an end-product (Bell, 2010). In general, there are four types of projects: information and research projects, survey projects, production projects, and performance/organizational projects (Haines, 1989). However, considering the difference in the ways that information is reported as part of a culminating activity, PBL projects are divided into three types: production projects, performance projects and organizational projects (Haines, 1989).

Researchers believed that PBL holds constructivism as its theoretical basis. Constructivism claims that a person cannot gain knowledge by being taught but must be constructed on his own (Benson, 2005). Thus, the teacher is not a knowledge-giver in a teachinglearning process but must be an instructor to help the students' self-directed efforts (Benson, 2005). The socio-cultural approach of Vygotsky $(1978,1981)$ may lend a much more powerful theoretical framework to understand PBL when it provides that the learning process possesses the nature of the social interaction between two or more people with differences in skills and knowledge. In the concept known as the Zone of Proximal Development, Vygotsky (1978) noted that "the distance between the actual development level as determined by independent problem solving and the level of potential development as determined through problem-solving under adult guidance or in collaboration with more capable peers" (p. 86). The problem-solving method considers the classroom as a miniature society in which the students collaborate to provide solutions to a problem. Throughout this process, the students construct their skills and knowledge.

\subsection{Project-based learning, motivation and autonomy}

Research has indicated that PBL is an effective approach to improve motivation and student independence in learning (e.g., Benson, 2007; Levine, 2004; Maftoon, Birjandi, \& Ahmadi, 2013; Smithers, 2014). McCarthy (2010) finds that in the English course many Japanese students carried with them the learning experiences of being passive learners within a yakudoku (grammar-translation) system, where they were dependent on the teacher to impart knowledge. This author also gives a comparison between a traditional classroom (grammartranslation) and a PBL-integrated one which motivates students to learn by doing and hold accountable to each other and the teacher.

PBL is meaningful in enhancing motivation and autonomy of the learners, not to mention other skills necessary for their jobs in the future. However, to gain desired outcomes, the projects implemented in PBL should consider several key-points (Dörnyei \& Ushioda, 2011; Egbert, 2003). These include a balance of student capability and challenge, concrete goals, detailed processes, and a controllable role of student in the entire process. Assuming the lack of 
autonomy and motivation in learning has been a problem among participants, this study considered these four elements in developing its project in an attempt to find out a solution.

\subsection{Project-based learning within CHC context}

While research on PBL-integrated Japanese language classrooms is rare in general and extremely rare in the CHC context in particular, many articles are available concerning the investigation of PBL in ESL and EFL courses. Since this work deals with Japanese speaking course for Vietnamese students in Vietnam where there is a lack of authentic Japanese environment, those studies that investigated PBL-integrated classrooms in EFL within CHC contexts are noteworthy for the reference and finding discussion of this study. From CHC universities such as those in China, Japan, Korea, and Vietnam, many studies of implementing PBL in EFL classrooms can serve as positive examples. The following will briefly discuss some relevant research.

In Mainland China, implementing PBL in college English listening and speaking class, Zhang (2015) discovered that the project helped the student learning motivation and autonomy. The researcher concluded that PBL was "a viable and flexible alternative to traditional English teaching and learning" (Zhang, 2015, p. 40). In Japan, group survey projects were used successfully in freshman English classes at a national university (Tomei, Glick, \& Holst, 1999). In such an environment which Susser (1998) described as “Japan's silent, authoritarian classrooms" (p. 59), the authors claimed that the survey projects had indeed enhanced the students' creativity and imagination. Meanwhile, Foss, Carney, McDonald, and Rooks (2007) examined the effectiveness of the project-based teaching approach in a short-term intensive English program for Japanese university EFL students by four distinct projects. These researchers found that project-based instruction was "a viable and flexible alternative to traditional intensive English coursework" (p. 1). In Korea, where Florea (2011) saw the picture of "the teacher speaks, students take notes about the information without really interacting with it except via rote" (p. 47), a study using video production projects resulted in a positive influence on students' motivation and enhancing their cooperation skills (Shin, 2018). Other research relating to arts project-based language program for Korean EFL college students also led to a meaningfully enhancing students' positive attitudes towards their major and the language learning together with an improvement in vocabulary and self-esteem (Park \& Lee, 2019). In the Vietnamese context, it seems that a modest number of published papers dealing with implementing PBL in teaching English. Canh (2017) has investigated students' attitude towards the use of project works to enhance their autonomous learning in an English-speaking class employing questionnaires, semi-structured interviews and class observation. The results showed that the students had positive attitudes towards project implementation. Loi (2017) described the impact of project work in teaching English language skills on the learner autonomy of students in an English Language Teacher Education program. Using the instruments of questionnaire and group interviews, this researcher demonstrated that the students gained a higher degree of learner autonomy after participating in project work.

\subsection{This project}

Being designed for a Japanese language course, the project conducted in this study was a production project with posters and video clips as final products. In this project, the participants formed into groups. Each group chose a task of designing a travel package for one type of tourism available in Dalat such as eco-, spiritual-, cultural-, food-, golf-, and adventure-tourism. They had a poster template presently using in the Japanese tourism industry to rely on as well as the instructor helps whenever needed. Having basing on the claims of Dewey (1938) and 
Thomas (2000) about PBL, it aimed to enhance student motivation, autonomy and language acquisition as a part of the entire language course. Namely, the project was not the only work students were evaluated on, other course assessment methods were also used, such as oral exams and written exams, for instance. Furthermore, a rubric was designed for the evaluation to help students when planning their work and to evaluate the quality of students' constructed responses during the process.

In summary, previous studies indicate that PBL is quite suitable for developing students' motivation and autonomy, not to mention other useful skills. In CHC contexts of EFL where the most salient learning traits of the student are information-receiving, passive, rote-learning, and teacher-centered, successful PBL requires having carefully designed projects. However, there is no work reported on how accepting students from CHCs such as Vietnam are of PBL in Japanese language classrooms. The present study developed a project within a Japanese language course for students of Yersin University of Dalat, Vietnam and evaluated it by the following four research questions:

1) What are the effects of the PBL project on students' motivation in Japanese learning?

2) Can students within a Vietnamese university successfully carry out a PBL project autonomously?

3) What are the students' perceptions towards PBT assignment in a Japanese speaking course?

4) Does a PBL project is suitable for the student to gain language acquisition?

\section{Methodology}

\subsection{Participants}

This study was participated by a total of 31 students, with ages ranging from 21 to 23 , enrolled in Japanese Language VI in the academic year 2020. The participants, being 02 males $(6.5 \%)$ and 29 females $(93.55 \%)$ are studying at the Department of Foreign Languages, the Yersin University of Da Lat and have studied five Japanese language courses named Japanese Language I-V. When the final assessment of the Japanese Language VI course had completed, the students helped to answer a questionnaire for ten minutes in the classroom. Before doing that, they were clearly explained every single item and assured that their responses would not affect their assessment of any other course and be confidentially used only for research purposes.

\subsection{Instruments}

This study used a questionnaire written in Vietnamese to collect quantitative data. Parts 2, 3 , and 4 of the questionnaire are a literature-reported version modified to accommodate the objectives of the current study. The first part aims to collect personal information of the students. Part 2 consisted of 03 items aiming to measure student motivation on doing the project work. The statements of this part are those used in previous EFL studies in task motivation (Dörnyei \& Ushioda, 2011; Grant, 2017). Basing on questions reported in published articles in the area of EFL student autonomy (Benson, 2007; Grant, 2017), Part 3 comprised of 03 items to investigate the extent of student autonomy. Part 4 was for the students to self-evaluate their language acquisition from the project. The statements of Parts 2, 3, and 4 are scored employing a Likerttype scale with five response options, ranging from 5 (strongly agree) to 1 (strongly disagree). Tables 1, 2, and 3 in the Result and Discussion section below show the statements of Parts 2, 3, and 4. 


\subsection{Analyses}

All the quantitative data were coded and processed using the IBM SPSS Statistics first to get descriptive statistics, and then the internal consistency by performing a scale reliability test. The reliability analysis performance was for Parts 2, 3, and 4 as a whole. Pearson's correlation tests were to find out any statistical relationship among items. Along the five-point Likert scale, averages of 5.0-4.5 are considered very favourable, 4.4-3.5 favourable, 3.4-2.5 neutral, 2.4-1.5 unfavourable, 1.4-1.0 strongly unfavourable (Oxford, 1990; Oxford \& Burry-Stock, 1995). For more details, the averages of neutral 3.4-2.5 are subdivided into two smaller ranges of 3.4-3.0 and 2.9-2.5 and evaluated as slightly favourable and slightly unfavourable, respectively.

\section{Results and discussion}

\subsection{Reliability analysis}

Reliability analysis was carried out on the perceived task values scale comprising 10 items of motivation (Part 2), autonomy (Part 3), and learning acquisition (Part 4). Cronbach's alpha showed the combined three parts of the questionnaire to reach $\alpha=0.872$, a value which is considered fairly high reliability by many researchers (Taber, 2018).

\subsection{The participants' motivations towards the project}

Since research on PBL-integrated Japanese language classrooms is rare, and both English and Japanese are foreign languages in Vietnam, the following discussion deals with literature reported on EFL studies.

Motivation is one of the most influential factors of language learning success. By a theory known as self-determination, Deci and co-workers distinguished intrinsic motivation from extrinsic motivation (Deci \& Ryan, 1985; Deci \& Ryan, 2000; Deci, Vallerand, Pelletier, \& Ryan, 1991). Intrinsic motivation relates to learners' enjoyment in learning a foreign language for its own sake or because of feeling interesting, while extrinsic motivation concerns with something from outside environments such as receiving rewards and avoiding punishment. Many researchers agreed that intrinsic motivation is more important and sustainable than extrinsic one since it is a cause of learning success and psychological satisfaction. Using the words 'enjoy', 'like', and 'feel better', this study aimed to evaluate intrinsic motivation. The motivations of the students towards the implemented project appear to be favourable according to the results shown in Table 1.

\section{Table 1}

Follow-up questionaire motivation items $(n=31)$

\begin{tabular}{clcc}
\hline Items & \multicolumn{1}{c}{ Statements } & $\mathbf{M}^{a}$ & SD \\
\hline 1 & I enjoyed this project & $\underline{4.10}$ & $\underline{0.65}$ \\
2 & I would like to do more projects like this one & $\underline{3.65}$ & $\underline{0.61}$ \\
3 & This project was better than the other assignments in this class & $\underline{3.81}$ & $\underline{0.65}$ \\
\hline${ }^{a}=$ & Strongly agree, $4=$ Agree, $3=$ Neutral, 2 = Disagree, 1 = Strongly disagree & \\
\hline
\end{tabular}

Source: The researcher's data analysis

The participants in this project live in the environment of Vietnamese language and culture and have not much chance to use Japanese. This learning context is similar to that of EFL students. Furthermore, Vietnamese grammar, linguistics features, and also presentations differ 
from that of Japanese. Therefore, serving as learning materials, their background knowledge helps to enhance content relevance and learning motivation (Farouck, 2016; Tomlinson, 2005; Wachob, 2006). The positive quantitative results shown in Table 1 prove a balance of student capability and challenge in the project has been made (Dörnyei \& Ushioda, 2011; Egbert, 2003). Attitude is one primary motivating factor in language learning, (Gardner, 1985). The favourable responses to the statements: I enjoyed this project $(\mathrm{M}=4.10)$ and This project was better than the other assignments in this class $(\mathrm{M}=3.81)$ probably mean that those respondents generally feel comfortable with the learning environment which the implemented PBL project has created. This result is consistent with the claim of Ahmed (2015) that a positive attitude stems from the favourable atmosphere of language learning and teaching context. In the cases of EFL students, it has also been found that female students have a favourable attitude towards English more than their male counterparts (Aldosari, 2014; Ghazvini \& Khajehpour, 2011). Unfortunately, the number of male participants in this research was statistically meaningless to explore the attitude difference between the two groups. Moreover, the slightly lower mean score of the responses to the statement $I$ would like to do more projects like this one $(\mathrm{M}=3.65)$ leads to confusion to some extent. PBL projects are complex tasks that students have to work relatively autonomously over an extended time (Jones et al., 1997; Thomas et al., 1999). Thus, one explanation may be that although the participants favoured this project in general, they had to invest much time to carry out it leaving less time for other purposes.

\subsection{The participants' autonomy in doing the project}

The results of questionnaire responses in the area of learning autonomy are in Table 2.

\section{Table 2}

Follow-up questionaire autonomy items $(n=31)$

\begin{tabular}{clcc}
\hline Items & \multicolumn{1}{c}{ Statements } & $\mathbf{M}^{a}$ & SD \\
\hline 4 & $\begin{array}{l}\text { This project helped me to seek the answer to my Japanese } \\
\text { language problem from sources other than my instructor }\end{array}$ & $\underline{3.97}$ & $\underline{0.84}$ \\
5 & $\begin{array}{l}\text { Help and reflections from the instructor were useful for me } \\
\text { to carry out this project }\end{array}$ & $\underline{4.26}$ & $\underline{0.58}$ \\
6 & $\begin{array}{l}\text { The rubric designed for this project is helpful for me to carry } \\
\text { out this project }\end{array}$ & $\underline{4.23}$ & $\underline{0.62}$ \\
\hline$a_{5}=$ Strongly a & &
\end{tabular}

${ }^{a} 5=$ Strongly agree, $4=$ Agree, $3=$ Neutral, $2=$ Disagree, $1=$ Strongly disagree

Source: The researcher's data analysis

As presented in Table 2, the results reveal that the respondents appeared to be willing to take responsibility in Japanese language learning. These three statements in the autonomy part of the questionnaire were to measure to what extent of autonomy the students can carry out a PBL project successfully. The statement This project helped me to seek the answer to my Japanese language problem from sources other than my instructor got a mean score of 3.97, which is considered positive. Namely, the respondents showed their ability to learn the target language autonomously. Thus, responses indicate that the implemented project has met its intended aim of student-centered learning. The finding in this study supports the results of many reports on PBL projects for EFL students (e.g., Canh, 2017; Grant, 2017; Smithers, 2014). However, the last two statements of Table 3 received higher mean scores, though not much, in comparison with that of the first one. These differences suggest that although the student autonomy was enhanced instructor's help was still indispensable for the success of the project. 


\subsection{The participants' learning acquisition}

As shown in Table 3, the students expressed that the project had been useful for them to acquire both the receptive and productive skills of the target language. Three of the four statements in this area of learning received positive responses with the mean scores ranging 3.653.71 , and one got slightly positive with a mean score of 3.19. Anxiety is one of the most vital components that affect the willingness to communicate in a foreign, or second, language (MacIntyre \& Doucette, 2010; Yashima, 2002). The lowest mean score of item 9 may indicate that the respondents still feel unconfident in using Japanese as a communicative tool. Their situations are even worse than that of EFL students since there are not many Japanese in Dalat, both temporary residents and tourists. Even though they had learned Japanese for five courses, named Japanese Language I-V, students still appear to lack confidence and to feel the anxiety to communicate in the target language.

\section{Table 3}

Follow-up questionaire learning items $(n=31)$

\begin{tabular}{cllc}
\hline Items & \multicolumn{1}{c}{ Statements } & $\mathbf{M}^{a}$ & SD \\
\hline 7 & $\begin{array}{l}\text { I learnt a lot about the Japanese language from doing this } \\
\text { project, doing my presentation and watching other students' } \\
\text { presentations }\end{array}$ & $\underline{3.71}$ & $\underline{0.64}$ \\
8 & $\begin{array}{l}\text { I discovered something new about the Japanese sentence } \\
\text { pattern and expression manner from doing this project and } \\
\text { watching other students' presentations }\end{array}$ & $\underline{3.71}$ & $\underline{0.74}$ \\
9 & $\begin{array}{l}\text { I improved my willingness to communicating very much } \\
\text { from doing this project, doing my presentation and watching } \\
\text { other students' presentations }\end{array}$ & $\underline{3.19}$ & $\underline{0.65}$ \\
10 & $\begin{array}{l}\text { My achievement from the process of this project boosted my } \\
\text { self-esteem in doing my job in the future }\end{array}$ & $\underline{3.65}$ & $\underline{0.61}$ \\
\hline a = Strongly agree, 4 = Agree, 3 = Neutral, 2 = Disagree, 1 = Strongly disagree & \\
\hline
\end{tabular}

Source: The researcher's data analysis

\subsection{Relationships among statements}

Pearson's product-moment correlation analysis has been conducted for every two statements of Tables 1,2, and 3 to examine if there is any significant relationship. The results are in Table 4. As shown, a significant positive correlation existed between statements 1 and 2. That means the more enjoyable the students feel, the more likely participating in future projects they are. There were also positive correlations between statements 1-10, 2-7, 2-10, and 3-7. These significant relationships assert that the respondents were supportive of the project because it gave them not only a chance to learn Japanese but other benefits as well. These findings support the claim of Gardner (1985) that learners who have positive attitudes learn more, and also learners who learn well acquire positive attitudes. 


\section{Table 4}

Results of Pearson' correlation tests

\begin{tabular}{|c|c|c|c|c|}
\hline Items & & 1 & 2 & 3 \\
\hline & Statements & $\begin{array}{l}\text { I enjoyed } \\
\text { this } \\
\text { project }\end{array}$ & $\begin{array}{l}\text { I would like } \\
\text { to do more } \\
\text { projects like } \\
\text { this one }\end{array}$ & $\begin{array}{l}\text { This project } \\
\text { was better than } \\
\text { the other } \\
\text { assignments in } \\
\text { this class }\end{array}$ \\
\hline 2 & $\begin{array}{l}\text { I would like to do more projects like this } \\
\text { one }\end{array}$ & $.595 * *$ & & \\
\hline 3 & $\begin{array}{l}\text { This project was better than the other } \\
\text { assignments in this class }\end{array}$ & & & \\
\hline 7 & $\begin{array}{l}\text { I learnt a lot about the Japanese language } \\
\text { from doing this project, doing my } \\
\text { presentation and watching other students } \\
\text { presentations }\end{array}$ & & $.410^{*}$ & $.496 * *$ \\
\hline 10 & $\begin{array}{l}\text { My achievement from the process of this } \\
\text { project boosted my self-esteem in doing } \\
\text { my job in the future }\end{array}$ & $.511 * *$ & $.369 *$ & \\
\hline
\end{tabular}

**. Correlation is significant at the 0.01 level (2-tailed)

*. Correlation is significant at the 0.05 level (2-tailed)

Source: Data analysis result of the research

\section{Conclusion}

This study investigates the student perceptions of a PBL project developed for a Japanese language course in Vietnam, where the most salient character traits of student learning are passive, rote learning, and teacher-centered, as viewed by many researchers. This investigation concludes that PBL appears to be suitable for students within the Vietnamese context. At the beginning of the course, the participants did not have sufficient ability to communicate in the target language due to both a lack of chance to practice and probably, traditional language learning methods. The findings of this research showed that they held positive attitudes towards taking charge of their learning activity. This expression is much meaningful since, according to Gardner (1985), the learners' positive or negative attitude may determine their success or failure in learning and acquiring the language. It should note that this study has some limitations, though. First of all, the number of male students was not statistically equivalent to that of female counterparts to analyze if there is any significant difference between the two groups. The investigation also lacked pre-test questionnaire evaluations to measure the quantitative achievements of the project implementation. 


\section{References}

Ahmed, S. (2015). Attitudes towards English language learning among EFL learners at UMSKAL. Journal of Education and Practice, 6(18), 6-16.

Aldosari, H. S. (2014). The entwined effects of attitude, motivation and gender on EFL learning: A correlation study. Studies in Literature and Language, 8(1), 1-5. doi:10.3968/j.sll.1923156320140801.4183

Beckett, G., \& Slater, T. (2019). Global perspectives on project-based language learning, teaching, and assessment: Key approaches, technology tools, and frameworks. Oxon, UK: Routledge.

Bell, S. (2010). Project-based learning for the 21st century: Skills for the future. Clearing House, 83(2), 39-43. doi:10.1080/00098650903505415

Benson, P. (2005). Autonomy. In J. Cummins \& C. Davison (Eds.), The international handbook of English language teaching. Norwell, MA: Springer.

Benson, P. (2007). Autonomy in language teaching and learning. Language Teaching, 40(1), 2140. doi:10.1017/S0261444806003958

Canh, T. T. T. (2017). Exploring Vietnamese students' attitude towards project works in enhancing autonomous learning in English speaking class. The Normal Lights, 11(2), 86-108.

Condliffe, B., Quint, J., Visher, G. M., Bangser, R. M., Drohojowska, S., Saco, L., \& Nelson, E. (2017). Project-based learning: A literature review. Retrieved October 20, 2018, from ERIC website: https://eric.ed.gov/?id=ED578933

Deci, E. L., \& Ryan, R. M. (1985). Intrinsic motivation and self-determination in human behavior. New York, NY: Plenum Press.

Deci, E. L., \& Ryan, R. M. (2000). The "what" and "why" of goal pursuits: Human needs and the self-determination of behavior. Psychological Inquiry, 11, 227-268. doi:10.1207/S15327965PLI1104_01

Deci, E. L., Vallerand, R. J., Pelletier, L. G., \& Ryan, R. M. (1991). Motivation in education: The self-determination perspective. Educational Psychologist, 26, 325-346. doi:10.1207/s15326985ep2603\&4_6

Dewey, J. (1938). Experience and education. New York, NY: Touchstone - Simon \& Schuster.

Dörnyei, Z., \& Ushioda, E. (2011). Teaching and researching motivation (2nd ed.). Harlow, UK: Pearson Education.

Egbert, J. (2003). A study of flow theory in the foreign language classroom. The Modern Language Journal, 87(4), 499-518.

Farouck, I. (2016). A project-based language learning model for improving the willingness to communicate of EFL students. Proceedings of IMCIC - ICSIT, 135-150. Retrieved October 25, 2018, from http://www.iiis.org/CDs2016/CD2016Spring/papers/EB193TO.pdf

Florea, P. J. (2011). Using improvisational exercises for increasing speaking and listening skills. Asian EFL Journal, 52, 46-57.

Foss, P., Carney, N., McDonald, K., \& Rooks, M. (2007). Project-based learning activities for short-term intensive English programs. Asian EFL Journal, 23, 1-19. 
Gardner, R. C. (1985). Social psychology and second language learning: The role of attitudes and motivation. London, UK: Edward Arnold Publishers.

Ghazvini, S. D., \& Khajehpour, M. (2011). Attitudes and motivation in learning English as second language in high school students. Procedia Social and Behavioral Sciences, 15, 1209-1213. doi:10.1016/j.sbspro.2011.03.264

Grant, S. (2017). Implementing project-based language teaching in an Asian context: A university EAP writing course case study from Macau. Asian-Pacific Journal of Second and Foreign Language Education, 2(4), 1-13. doi:10.1186/s40862-017-0027-x

Haines, S. (1989). Projects for EFL classroom: Resource material for teachers. Walton-onThames Surrey, UK: Nelton.

Jones, B. F., Rasmussen, C. M., \& Moffitt, M. C. (1997). Real-life problem solving: A collaborative approach to interdisciplinary learning. Washington, DC: American Psychological Association.

Levine, G. S. (2004). Global simulation: A student-centered, task-based format for intermediate foreign language courses. Foreign Language Annals, 37(1), 26-36. doi:10.1111/j.19449720.2004.tb02170.x

Loi, N. V. (2017). Promoting learner autonomy: Lesson from using project work as a supplement in English skills courses. Can Tho University Journal of Science, 7, 118-125. doi:10.22144/ctu.jen.2017.057

MacIntyre, P. D., \& Doucette, J. (2010). Willingness to communicate and action control. International Journal of Educational Technology and Applied Linguistics, 38(2), 161-171.

Maftoon, P., Birjandi, P., \& Ahmadi, A. (2013). The relationship between project-based instruction and motivation: A study of EFL learners in Iran. Theory and Practice in Language Studies, 3(9), 1630-1638. doi:10.4304/tpls.3.9.1630-1638

McCarthy, T. (2010). Integrating PBL into a traditional skills-based curriculum to foster learner autonomy: An action research. The Journal of Kanda University of International Studies, 1(22), 221-244.

Nguyen, C. T. (2014). How Vietnamese student adapt to a new educational environment when studying in Australian institutes? A case study at La Trobe University, VNU. Journal of Science Education Research, 30(3), 1-11.

Oxford, R. L. (1990). Language learning strategies: What every teacher should know. Boston, MA: Heinle \& Heinle.

Oxford, R. L., \& Burry-Stock, J. A. (1995). Assessing the use of language learning strategies worldwide with the ESL/EFL version of the strategy inventory for language learning (SILL). System, 23, 1-23.

Park, P., \& Lee, E. (2019). The impact of an arts project-based language program to enhance EFL learning. The Journal of Asia TEFL, 16(4), 1232-1250. doi:10.18823/asiatefl.2019.16.4.11.1232

Shin, M.-H. (2018). Effects of project-based learning on students' motivation and self-efficacy. English Teaching, 73(1), 95-114. doi:10.15858/engtea.73.1.201803.95

Smithers, W. R. (2014). Using projects to increase autonomy, motivation, and language learning. Osaka JALT Journal, 19-32. 
Susser, B. (1998). EFL's othering of Japan: Orientalism in English language teaching. JALT Journal, 20(1), 49-82.

Taber, K. S. (2018). The use of Cronbach's Alpha when developing and reporting research instruments in science education. Research in Science Education, 48, 1273-1296.

Thomas, J. W. (2000). A review of research on project-based learning. Retrieved October 27, 2018, from http://www.bobpearlman.org/BestPractices/PBL_Research.pdf

Thomas, J. W., Mergendoller, J. R., \& Michaelson, A. (1999). Project-based learning: A handbook for middle and high school teachers. Novato, CA: The Buck Institute for Education.

Thompson, J. (2009). Changing chalk and talk: The reform of teaching methods in Vietnamese higher education. Retrieved May 10, 2018, from https://pdfs.semanticscholar.org/b1a9/016456222f02bdf2b071f1f13782403793a9.pdf

Tomei, J., Glick, C., \& Holst, M. (1999). Project work in the Japanese university classroom. The Language Teacher, 23(3), 1-7.

Tomlinson, B. (2005). The future for ELT materials in Asia. Electronic Journal of Foreign Language Teaching, 2(2), 5-13.

Vygotsky, L. S. (1978). Mind in society; The development of higher mental processes. Cambridge, MA: Harvard University Press.

Vygotsky, L. S. (1981). The genesis of higher mental function. In J. V. Wertsch (Ed.), The concept of activity in Soviet psychology (pp. 144-188). Armonk, NY: Sharp.

Wachob, P. (2006). Methods and materials for motivation and learner autonomy. Reflections on English Language Teaching, 5(1), 93-122. doi:10.26877/eternal.v6i1.2293

Yashima, T. (2002). Willingness to communicate in a second language: The Japanese EFL context. The Modern Language Journal, 86, 54-66.

Zhang, Y. (2015). Project-based learning in Chinese college English listening and speaking course: From theory to practice. Canadian Social Science, 11(9), 40-44. doi:10.3968/7532 